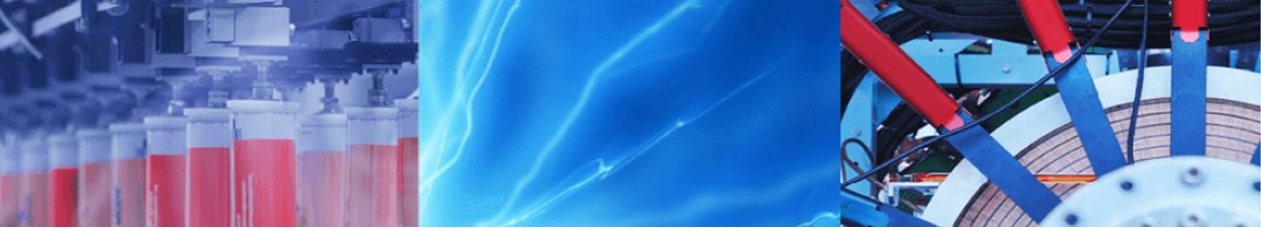

Research Article

\title{
Groundwater quality evaluation of Shiraz City, Iran using multivariate and geostatistical techniques
}

\author{
Razieh Alamdar ${ }^{1} \cdot \operatorname{Vinod~Kumar}^{2}\left[\right.$ ] Tahereh Moghtaderi $^{1} \cdot$ Seyed Javad Naghibi ${ }^{1,3}$
}

(c) Springer Nature Switzerland AG 2019

\begin{abstract}
Groundwater is vital water resource for domestic, agricultural and industrial purposes in Shiraz City, Iran. Management of groundwater with respect to quality and quantity is decisive subject in order to accomplish the increasing requirements for water. In the present paper, evaluation of groundwater parameters, viz., $\mathrm{pH}$, electrical conductivity (EC), major cations $\left(\mathrm{K}^{+}, \mathrm{Na}^{+}, \mathrm{Ca}^{2+}\right.$ and $\left.\mathrm{Mg}^{2+}\right)$, major anions $\left(\mathrm{Cl}^{-}\right.$and $\left.\mathrm{HCO}_{3}{ }^{-}\right), \mathrm{NO}_{3}{ }^{-}, \mathrm{SO}_{4}{ }^{2-}$, total dissolved solids (TDS), alkalinity, hardness, sodium absorption ratio (SAR) and $\mathrm{Na} \%$ were done from Shiraz City, Iran. Consequently, 80 groundwater samples were collected from different sites in June 2017. The results of different parameters were compared with the standard guideline prescribed by the World Health Organization (WHO) for drinking and public health purposes. From the results, it was concluded that $62.5 \%$ samples exceeded for $\mathrm{EC}$ values, $12.5 \%$ samples for $\mathrm{Na}^{+}, 30 \%$ samples for $\mathrm{Ca}^{2+}, 97.5 \%$ samples for $\mathrm{Mg}^{2+}$ and TDS, $28.7 \%$ samples for $\mathrm{Cl}^{-}$, and $40 \%$ samples for $\mathrm{SO}_{4}{ }^{2-}$ contents as recommended by WHO. The Na\% values ranged from 5.25 to 38.59 , whereas SAR values varied from 0.21 to $6.64 \mathrm{meq} / \mathrm{L}$. Results of Na\% and SAR indicated that groundwater is good for irrigation and domestic purposes. The results of $\mathrm{MGI}$ and $\mathrm{BEl}$ showed that $83.75 \%$ sampling sites showed shallow meteoric percolation type and $\mathrm{Na}+\mathrm{SO}_{4}$ type with less than one value respectively. Multivariate statistical analysis (cluster analysis and principal component analysis) and spatial maps showed that both anthropogenic activities such as cement factory, gas power plant, Rishmark factory and vegetable Oil Company, and natural processes like rock weathering are responsible for the contents of groundwater parameters.
\end{abstract}

Keywords Groundwater $\cdot$ SAR $\cdot$ Multivariate techniques $\cdot$ NMDS $\cdot$ Geostatistical analysis

\section{Introduction}

The good quality of drinking water is far behind for utmost populations throughout the world [1]. This is due to the reason that resources are contaminated at incessant rate due to unorganized industrialization and urbanization [2]. Presently, water quality is of key issue, because it is the source of poor health in major countries of the world [3, 4]. The countries which are growing, inappropriate access to clean drinking water is harmfully influencing the human health [5]. Population explosion and growing living standards are enhancing the requirement of water in urban areas and this requirement has put enormous pressure on the inadequate water resources [6]. The over utilization of groundwater associated with nominal renew leads to groundwater degradation and scarcity [7].

European Environment Agency framed policies regarding management of groundwater and to recognize point source pollutants as the primary initiative for the remediation. However, in many urbanized regions, pollutant plumes formed by single point sources commonly synchronize with prevalent pollution originated from diverse point sources [8]. The proper attention should be given to prevent and control the groundwater contamination in order to avoid expensive remediation, because groundwater contamination is invisible, complex and has prolonged

$\triangle$ Vinod Kumar, vinodverma507@gmail.com | 'Landscape and Green Spaces Organization of Shiraz Municipality, Shiraz, Iran. ${ }^{2}$ Department of Botany, DAV University, Jalandhar, Punjab 144012, India. ${ }^{3}$ Shiraz University, Shiraz, Iran. 
effects. To assess the probable effects of any contaminant in the groundwater pollution is an efficient strategy for management of groundwater $[9,10]$.

Aquifer systems are affected by the spatial and temporal alterations of natural as well as human activities. The associations and spatial variability of these aspects, limits and hierarchy of their associations between the constituents, statistically elucidated [11-13]. Geostatistics is important for spatial mapping of groundwater parameters, variograms are employed to determine spatial relationship, and the kriging variance is a role of geometric pattern. The kriging determination variances are independent and are associated to model variogram and the spatial organization of the sampling statistics. Kriging interpolation is applied to give the good variable nearness value of an approximate in association to the real value employing least square approach $[14,15]$. Multivariate techniques have been used to find the information from the large data and such techniques applied in exploratory data assessment as approaches to categorize samples and recognize pollution sources [16, 17]. Cluster analysis and principal component analysis techniques helps in interpretation of enormous parameters to accomplish a great understanding of the hydrochemical mechanisms engaged $[18,19]$. To improve organization of water resources on a local level, the objective of this research is to recognize and assess the interfering natural and human factors concerning with groundwater hydrochemistry in an urban area. Because of the multifaceted interactions between human and geogenic features influencing groundwater hydrochemistry, this study is distinctive in its application of integrated techniques hydrochemical exploration, geostatistics, and multivariate techniques in urban areas. To protect and maintain the speedily diminishing groundwater resources in urban regions, sophisticated evaluation methods are required to better recognize the relationships among landuse and natural and, human causes of pollution.

\section{Materials and methods}

\subsection{Study area}

The present study was accomplished in Shiraz megacity, 5th populated city of Iran with $223.4 \mathrm{~km}^{2}$ area positioned at $29^{\circ} 37^{\prime} 8^{\prime \prime} \mathrm{N}$ lat. and $52^{\circ} 31^{\prime} 14^{\prime \prime}$ E longitude (Fig. 1). About $1500 \mathrm{~m}$ is the surface elevation of this city from the sea level. The main direction of the Shiraz aquifer is from northwest to south east. The $1009 \mathrm{~km}^{2}$ Shiraz basin partly comprises of the watershed of the Khoshk seasonal river, which runs to Maharloo salt lake located to the south of the city. The hydraulic gradient of the eastern part is less than that of central and western parts. According to the
Iran Meteorological Organization (IRIMO) reports, the annual mean temperature and precipitation are $18.7^{\circ} \mathrm{C}$ and $324.2 \mathrm{~mm}$ respectively. The climatic condition in the surrounding study area is semi-arid. Approximate half of the water used for domestic and industrial purposes is supplied from deep and semi-deep wells dispersed in the area. Due to improper sewage system in the city, about $80-85 \%$ of the municipal water used, i.e., $250 \mathrm{~L}$ per cap. per day moves into the groundwater, mainly goes to Maharloo Salt Lake [20]. The area is waterlogged during wet years when the level of Khoshk River is high.

\subsection{Hydrological settings and aquifer formation}

The geophysical investigations in the Shiraz have established that Shiraz water bearing layer in more depths, it suffers from unsuitable quality. Studies showed that groundwater of Shiraz comprises of surface unconstrained aquifer and a deep aquifer [20]. Two seasonal rivers Khoshkrud and Chenarrahdar occured in Shiraz area. The seasonal Khoshkrud River enters in Golestan and Ghalat mountains heights after connecting with Khoshk River, it arrives in the Shiraz city. Agricultural runoff and industrial wastewater arrives into the river at the south eastern part of Shiraz. The geological information showed that the development that takes place in the area are from old to new such as Formation of Tarbor takes place during Campanian to Maastrichtian, Pabdeh-Gurpi developments occurred in Paleocene, formation of Sachun takes place in Paleocene, Jahrom formation occurred in Eocene, Asmari establishments takes place in Oligocene, Razak formation during Miocene, Agha Jari development occurred in Miocene to Pliocene, formation of Bakhtyari made in Pliocene to Pleistocen, and quarternary alluvial deposits [21].

Shiraz alluvial aquifer is formed during the Quaternary alluvium that comprises of grain sediments and moderate to fine grained clay particles carried by stream and flood wash of catchment geological units. The northern side comprises of coarse alluvium. Oligo-miocene carbonate formed from the Asmari-Jahrom, Miocene marl formed from Razak and Plio-Pleostocene conglomerate developed from the Bakhtyari form the catchment geological settings in Shiraz [22]. In addition to Shiraz alluvial aquifer, many karstic anticlines adjoining the Shiraz also provides drinking water to the peoples of city. The northern karstic aquifer is linked with the alluvial aquifer. Comprehensive pumping in the northern karstic aquifer has reversed the ground water flow route, taking place in alluvial aquifer water arriving the karstic aquifer [22]. 


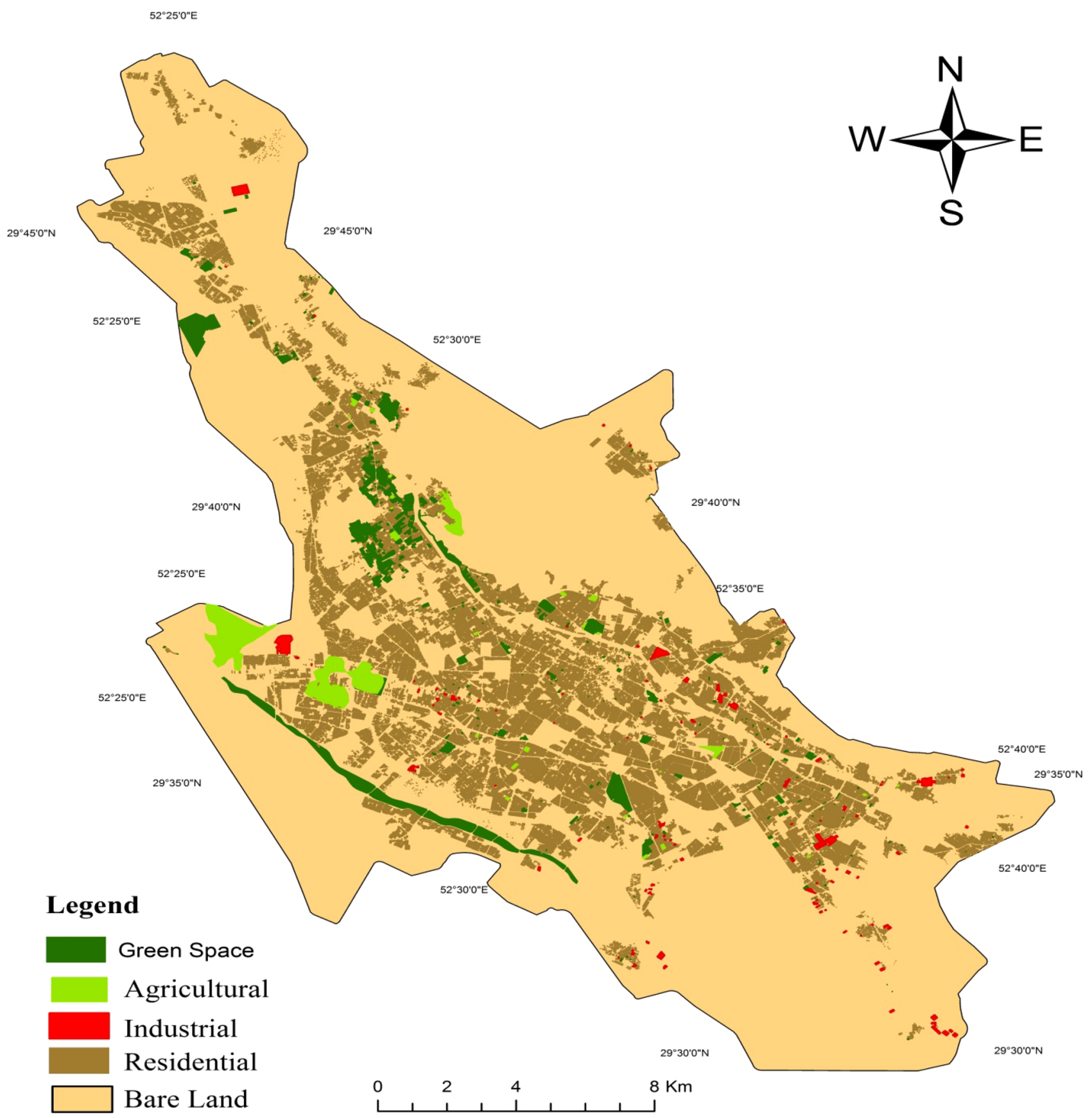

Fig. 1 Study area and location of sampling sites

\subsection{Sampling and analysis}

For the assessment of groundwater quality, samples were collected from 80 sites from the deep wells distributed throughout the area. Geographic coordinates of each sampling site was noted using geographic positioning system apparatus. All the samples were filtered and stored in 250$\mathrm{mL}$ polypropylene bottles cleaned with water samples and kept at temperatures below $4{ }^{\circ} \mathrm{C}$ to avoid unforeseeable variations in chemical constitution [23]. $\mathrm{pH}$ was determined by using $\mathrm{pH}$ meter (Metrohm 827). EC and TDS were measured by using EC meter (Hanna EC214). $\mathrm{SO}_{4}{ }^{2-}$ and $\mathrm{NO}_{3}{ }^{-}$content were measured in the groundwater by using HACH DR 5000 UV-Vis spectrophotometer. $\mathrm{Na}^{+}$and $\mathrm{K}^{+}$were determined by using flame photometer (Feter Electronic 405). $\mathrm{Ca}^{2+}, \mathrm{Mg}^{2+}$ and $\mathrm{HCO}_{3}{ }^{-}$were measured by EDTA titration method. $\mathrm{Cl}^{-}$was measured in the groundwater samples base on ASTM [24] method. Alkalinity 
was measured in the samples by using ETDA titration. Total hardness $(\mathrm{TH})$ was calculated by $\mathrm{TH}(\mathrm{mg} / \mathrm{L})=2.497$ $\mathrm{Ca}+4.115 \mathrm{Mg}[25]$.

\subsection{Spatial maps}

Spatial distribution maps for all the groundwater parameters were made in ArcGis software v. 10 using kriging approach.

\subsection{Statistical analysis}

The results were statistically analyzed by using descriptive statistics in PAST software v. 3.15. The data was also analyzed by using various multivariate techniques such as Pearson's correlation analysis $R$ programming software $v$. 3.1.3, Cluster analysis (CA) and principal component analysis (PCA) by SPSS software v. 16 and non-metric multidimensional scaling (NMDS) by PAST software v. 3.15. CA is mainly applied in hydrology with the objective to find out relationship among the variables $[26,27]$. In present work, we conducted a hierarchical CA following Ward's method and Euclidean distance $[28,29]$. Ward's method indicates that proximity between two clusters is the enhancement in squared error. The outcomes are shown in the form of dendrograms [30]. PCA is conducted to decrease the data and determine the common arrangements within a large data [31]. In hydrology, PCA is mainly applied in hydrochemical and hydrogeological works [32]. It permits decreasing the dimensions of data with a great number of correlated variables. The decrease is made by converting original data into a new set of data called principal components. The data was rotated by varimax rotation to enhance the precision of results [33].

\section{Results and discussion}

The physiochemical characteristics and statistical analysis for all the 80 groundwater samples were determined. Table 1 presents the mean, minimum, maximum, standard deviation, skewness, kurtosis and coefficient of variation for the groundwater samples. The $\mathrm{pH}$ of the groundwater samples ranged from 6.8 to 8.31 , indicating acidic to slightly alkaline nature of water. The $\mathrm{pH}$ values of present study were found within the range of world health organization [34] for drinking and public health purposes. The electrical conductivity varied from $518(\mu \mathrm{S} / \mathrm{cm})$ to 12160 $(\mu \mathrm{S} / \mathrm{cm})$ with average value of $1877.74(\mu \mathrm{S} / \mathrm{cm})$ for the present study. The maximum permissible limit of EC prescribed by WHO [34] is $1500(\mu \mathrm{S} / \mathrm{cm})$. About $62.5 \%$ samples exceeded WHO [34] limit for drinking water. The higher $E C$ values indicate enrichment of salts in the groundwater [35]. The $\mathrm{K}^{+}$content ranged from 39 to $2952.3 \mathrm{mg} / \mathrm{L}$ with mean value of $246.14 \mathrm{mg} / \mathrm{L}$. All the samples for $\mathrm{K}^{+}$, exceeded the value of WHO [34] for drinking water, i.e., $12 \mathrm{mg} / \mathrm{L}$. The $\mathrm{Na}^{+}$varied from 8.28 to $963.7 \mathrm{mg} / \mathrm{L}$ with average value of $113.6 \mathrm{mg} / \mathrm{L}$. About $12.5 \%$ samples exceeded the WHO [34] limit for drinking water. The maximum

Table 1 Descriptive statistics of groundwater parameters from Shiraz

\begin{tabular}{|c|c|c|c|c|c|c|c|c|c|}
\hline & Min & Max & Mean & SE & SD & Skewness & Kurtosis & C.V. & WHO (2011) \\
\hline $\mathrm{pH}$ & 6.8 & 8.31 & 7.17 & 0.03 & 0.24 & 1.66 & 5.63 & 3.30 & $6.5-8.5$ \\
\hline $\mathrm{EC}(\mu \mathrm{S} / \mathrm{cm})$ & 518 & 12,160 & 1877.74 & 148.98 & 1332.56 & 6.03 & 45.55 & 70.97 & 1500 \\
\hline $\mathrm{K}^{+}(\mathrm{mg} / \mathrm{L})$ & 39 & 2952.3 & 246.14 & 37.54 & 335.76 & 6.91 & 54.80 & 136.41 & 12 \\
\hline $\mathrm{Na}^{+}(\mathrm{mg} / \mathrm{L})$ & 8.28 & 963.7 & 113.60 & 12.91 & 115.45 & 5.24 & 37.26 & 101.63 & 200 \\
\hline $\mathrm{Ca}^{2+}(\mathrm{mg} / \mathrm{L})$ & 36.8 & 134 & 63.13 & 1.96 & 17.57 & 0.90 & 1.71 & 27.82 & 75 \\
\hline $\mathrm{Mg}^{2+}(\mathrm{mg} / \mathrm{L})$ & 33.6 & 874.8 & 125.69 & 10.67 & 95.41 & 6.36 & 49.07 & 75.91 & 50 \\
\hline $\mathrm{HCO}_{3}^{-}(\mathrm{mg} / \mathrm{L})$ & 146.4 & 463.6 & 358.07 & 7.33 & 65.57 & -0.82 & 0.23 & 18.31 & 500 \\
\hline $\mathrm{Cl}^{-}(\mathrm{mg} / \mathrm{L})$ & 28.4 & 2272 & 246.64 & 32.43 & 290.04 & 4.91 & 30.87 & 117.60 & 250 \\
\hline $\mathrm{SO}_{4}{ }^{2-}(\mathrm{mg} / \mathrm{L})$ & 4.8 & 2457.6 & 280.56 & 37.48 & 335.19 & 4.08 & 22.91 & 119.47 & 250 \\
\hline $\mathrm{NO}_{3}^{-}(\mathrm{mg} / \mathrm{L})$ & 0.16 & 8.96 & 4.31 & 0.29 & 2.59 & -0.72 & -0.92 & 60.12 & 45 \\
\hline Alkalinity (mg/L) & 144 & 456 & 352.20 & 7.21 & 64.50 & -0.82 & 0.23 & 18.31 & 600 \\
\hline Hardness (mg/L) & 230 & 3980 & 681.69 & 47.58 & 425.56 & 6.13 & 46.50 & 62.43 & 600 \\
\hline TDS (mg/L) & 331.52 & 7782.4 & 1201.75 & 95.35 & 852.84 & 6.03 & 45.55 & 70.97 & 500 \\
\hline $\mathrm{Na}(\%)$ & 5.25 & 38.59 & 24.05 & 0.93 & 8.29 & -0.04 & -0.50 & 34.45 & - \\
\hline SAR meq/L & 0.21 & 6.64 & 1.76 & 0.12 & 1.04 & 1.56 & 4.78 & 58.82 & - \\
\hline
\end{tabular}


allowable limit prescribed by WHO [34] is $200 \mathrm{mg} / \mathrm{L}$. High $\mathrm{EC}$ contributes to saline soil formation, while high $\mathrm{Na}^{+}$concentration forms alkaline soil [36]. $\mathrm{Ca}^{2+}$ ranged from 36.8 to $134 \mathrm{mg} / \mathrm{L}$ with average value of $63.13 \mathrm{mg} / \mathrm{L}$. The limit prescribed by WHO [34] for drinking water are $75 \mathrm{mg} / \mathrm{L}$. $30 \%$ samples exceeded the WHO limit for $\mathrm{Ca}^{2+}$ in the present study. $\mathrm{Mg}^{2+}$ varies from 33.6 to $874.8 \mathrm{mg} / \mathrm{L}$, and about $97.5 \%$ samples exceeded the limit of WHO [34] for drinking water. $\mathrm{HCO}_{3}{ }^{-}$content ranged from 146.4 to $463.6 \mathrm{mg} / \mathrm{L}$ with average value of $358.07 \mathrm{mg} / \mathrm{L}$. For all the sampling sites, $\mathrm{HCO}_{3}{ }^{-}$content was found lower than the WHO [34] for drinking water, i.e., $500 \mathrm{mg} / \mathrm{L}$. $\mathrm{Cl}^{-}$content varied from 28.4 to $2272 \mathrm{mg} / \mathrm{L}$ with average value of $246.6 \mathrm{mg} / \mathrm{L}$. The maximum allowable limit for $\mathrm{Cl}^{-}$is $250 \mathrm{mg} / \mathrm{L}$ as recommended by $\mathrm{WHO}$ [34] and about $28.7 \%$ samples exceeded the $\mathrm{WHO}$ [34] limit. $\mathrm{SO}_{4}{ }^{2-}$ content ranged from 4.8 to $2457.6 \mathrm{mg} / \mathrm{L}$ with mean value of $280.56 \mathrm{mg} / \mathrm{L}$. The limit prescribed by WHO [34] for $\mathrm{SO}_{4}{ }^{2-}$ is $250 \mathrm{mg} / \mathrm{L}$ and about $40 \%$ samples exceeded this limit for $\mathrm{SO}_{4}{ }^{2-}$ content. $\mathrm{NO}_{3}{ }^{-}$content varied from 0.16 to $8.96 \mathrm{mg} / \mathrm{L}$ with average value of $4.31 \mathrm{mg} / \mathrm{L}$. The limit recommended by WHO [34] for $\mathrm{NO}_{3}{ }^{-}$is $45 \mathrm{mg} / \mathrm{L}$, and all samples were found below this limit for $\mathrm{NO}_{3}{ }^{-}$content. TDS content ranged from 331.5 to $7782.4 \mathrm{mg} / \mathrm{L}$ with average value of $1201.7 \mathrm{mg} / \mathrm{L}$. The limit prescribed by WHO [34] for TDS is $500 \mathrm{mg} / \mathrm{L}$, and $97.5 \%$ samples exceeded this limit for TDS. The hardness values varied from 230 to $3980 \mathrm{mg} / \mathrm{L}$ with average value of $681.69 \mathrm{mg} / \mathrm{L}$. The level of hardness is categorized as: 0-75 soft, 75-150 moderately hard, 150-300 hard, and $>300$ very hard [37]. $97.5 \%$ samples showed that hardness content is very hard for the present study. The alkalinity values ranged from 144 to $456 \mathrm{mg} / \mathrm{L}$ with mean value of $352.2 \mathrm{mg} / \mathrm{L}$. The alkalinity values were found lower than the maximum limits recommended by WHO [34] for drinking water such as $600 \mathrm{mg} / \mathrm{L}$. The skewness and kurtosis of $\mathrm{pH}, \mathrm{EC}, \mathrm{K}^{+}, \mathrm{Na}^{+}, \mathrm{Mg}^{2+}, \mathrm{Cl}^{-}, \mathrm{SO}_{4}{ }^{2-}$, hardness and TDS were found greater than one representing right handed skewness and leptokurtic [38]. $\mathrm{K}^{+}$followed by $\mathrm{SO}_{4}{ }^{2-}, \mathrm{Cl}^{-}$and $\mathrm{Na}^{+}$ showed greatest variation in the groundwater samples of the present study. Figure 2 presents the spatial distribution of $\mathrm{pH}, \mathrm{EC}, \mathrm{SO}_{4}, \mathrm{NO}_{3}, \mathrm{Cl}^{-}, \mathrm{HCO}_{3}$, alkalinity, hardness and TDS for the present study on the basis of kriging method. From the spatial maps, it was predicated that both anthropogenic activities like cement factory, gas power plant, Rishmark factory and vegetable Oil Company, and natural processes like rock weathering are responsible for the contents of groundwater parameters.

Pearson's correlation analysis was applied to groundwater parameters to find relationship among different parameters (Fig. 3). They presented efficient method to indicate the associations between diverse variables and consequently useful in understanding the contributing aspects and sources of chemical constituents. $\mathrm{pH}$ showed correlation with $\mathrm{HCO}_{3}$ and alkalinity. Correlation of $\mathrm{NO}_{3}$ found with $\mathrm{Ca}$. The correlation of $\mathrm{EC}$ existed with $\mathrm{K}, \mathrm{Na}, \mathrm{Ca}$, $\mathrm{Mg}, \mathrm{Cl}, \mathrm{SO} 4$, Hardness, TDS and SAR. The $\mathrm{K}, \mathrm{Na}, \mathrm{Ca}$ and $\mathrm{Mg}$ showed correlation with $\mathrm{Cl}, \mathrm{SO}_{4}$, hardness, TDS and SAR. $\mathrm{Cl}, \mathrm{SO}_{4}$, hardness, TDS and SAR showed correlation with each other. The correlation of EC and TDS is attributed by the fact that dissolved constituents cause enhanced ionic content and EC content [39]. The correlations results of different ions showed that these ions involve diverse physical as well as chemical processes such as oxidation/reduction reactions as well as ion exchange in groundwater aquifers, indicating that similar factor have strong influence on them $[40,41]$. The correlation of $\mathrm{Cl}$ and SO4 usually used to recognize the processes of salinity in arid and semiarid places [42].

\subsection{Sodium ( $\mathrm{Na}) \%$ and Sodium absorption ratio (SAR)}

$\mathrm{Na} \%$ is a widespread index calculated to evaluate the acceptability of groundwater. Na concentration in groundwater is exchanged with $\mathrm{Ca}^{2+}$ and $\mathrm{Mg}^{2+}$ of clay particles of the soil, which leads to decrease of soil permeability, internal drainage and air circulation. \% $\mathrm{Na}$ is computed by following Wilcox [43]:

$$
\mathrm{Na} \%=\frac{\left(\mathrm{Na}^{+}+\mathrm{K}^{+}\right)}{\left(\mathrm{Ca}^{2+}+\mathrm{Mg}^{2+}+\mathrm{Na}^{+}+\mathrm{K}^{+}\right)} \times 100
$$

Higher percentage of $\mathrm{Na}$ in groundwater decreases the permeability of the soil. The Na\% varies from 5.25 to 38.59 with average value of 24.05 . The $31.2 \%$ samples showed $<20 \mathrm{Na} \%$, indicating excellent for irrigation and agricultural practices, and $68.7 \%$ samples were fall in the category of 30-40 Na\%, indicating good category of groundwater and suitable for irrigation and agricultural practices. Figure 2 presents the spatial distribution of $\%$ $\mathrm{Na}$ for the present study on the basis of kriging approach.

SAR is vital parameter to evaluate the groundwater quality. It represents the impact of relative cation content on $\mathrm{Na}^{2+}$ accumulation in the soil, is applied to assess the Sodicity risk of water. Soil permeability reduces with the enhancement in $\mathrm{Na}^{2+}$ in relation to $\mathrm{Ca}^{2+}$ and $\mathrm{Mg}^{2+}$ concentrations. It is computed by following Hem [44]: 

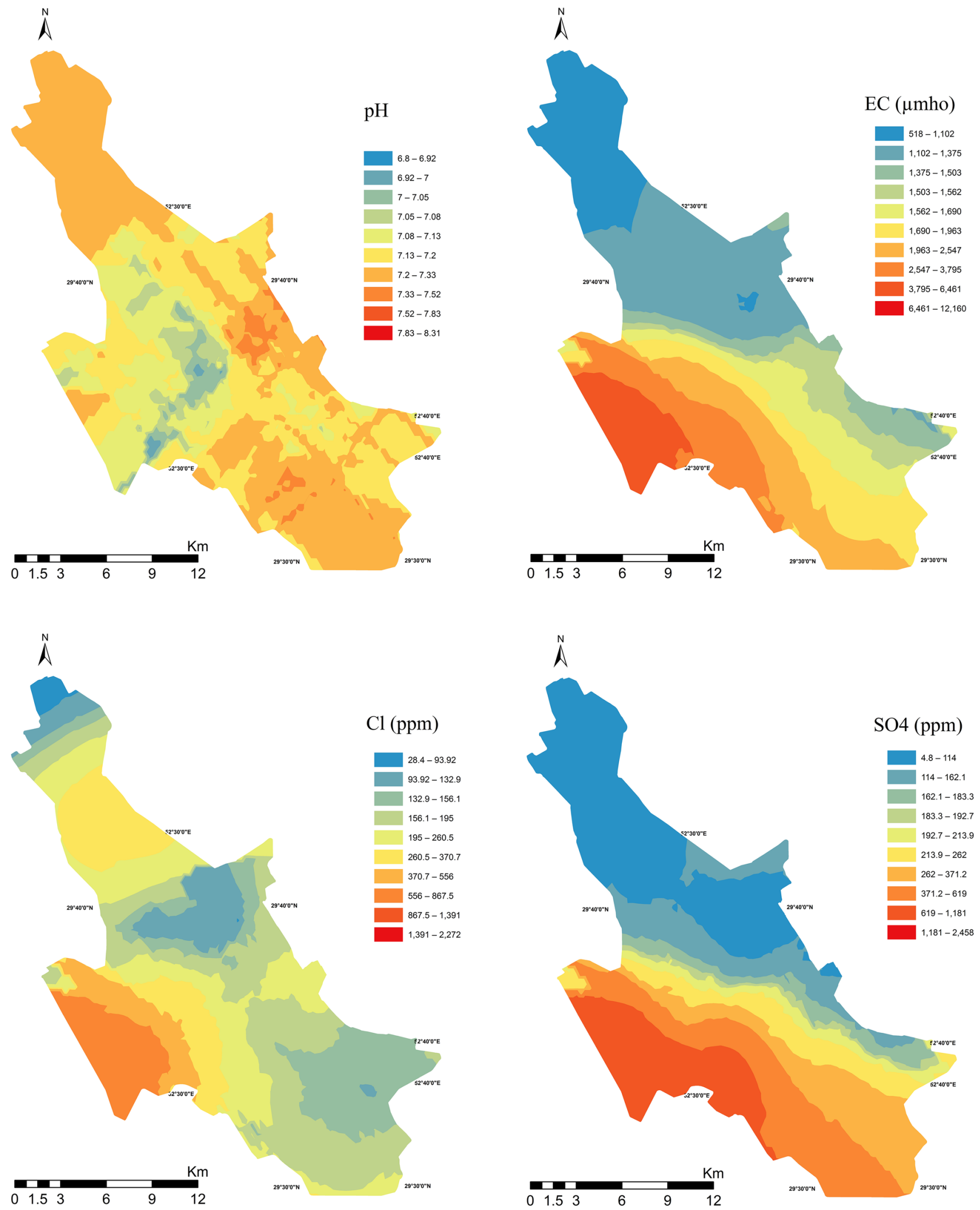

Fig. 2 Spatial distribution of groundwater parameters ( $\mathrm{pH}, \mathrm{EC}, \mathrm{Cl}, \mathrm{SO}_{4}, \mathrm{NO}_{3}$, alkalinity, hardness, TDS, $\mathrm{Na} \%$ and SAR) 

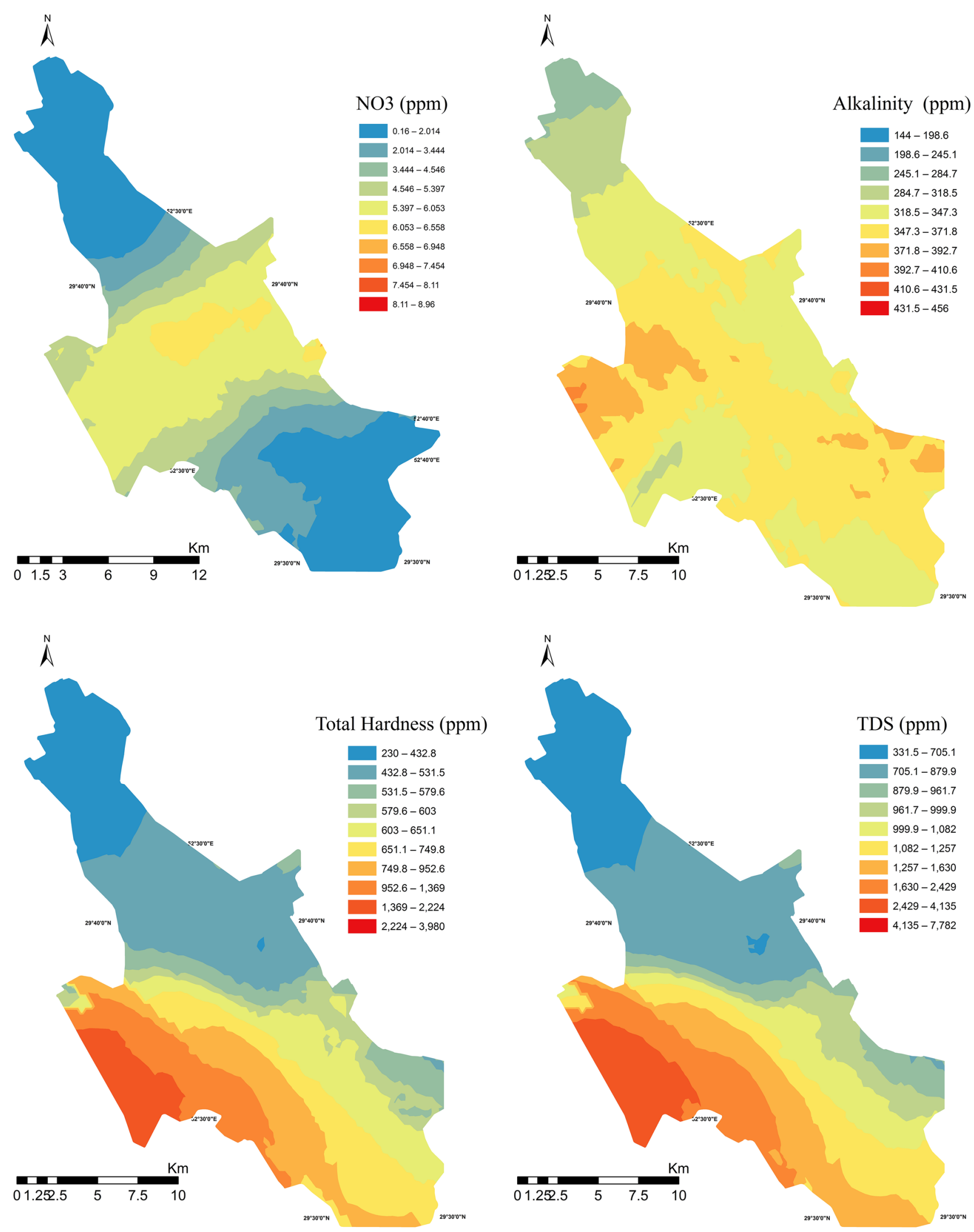

Fig. 2 (continued) 


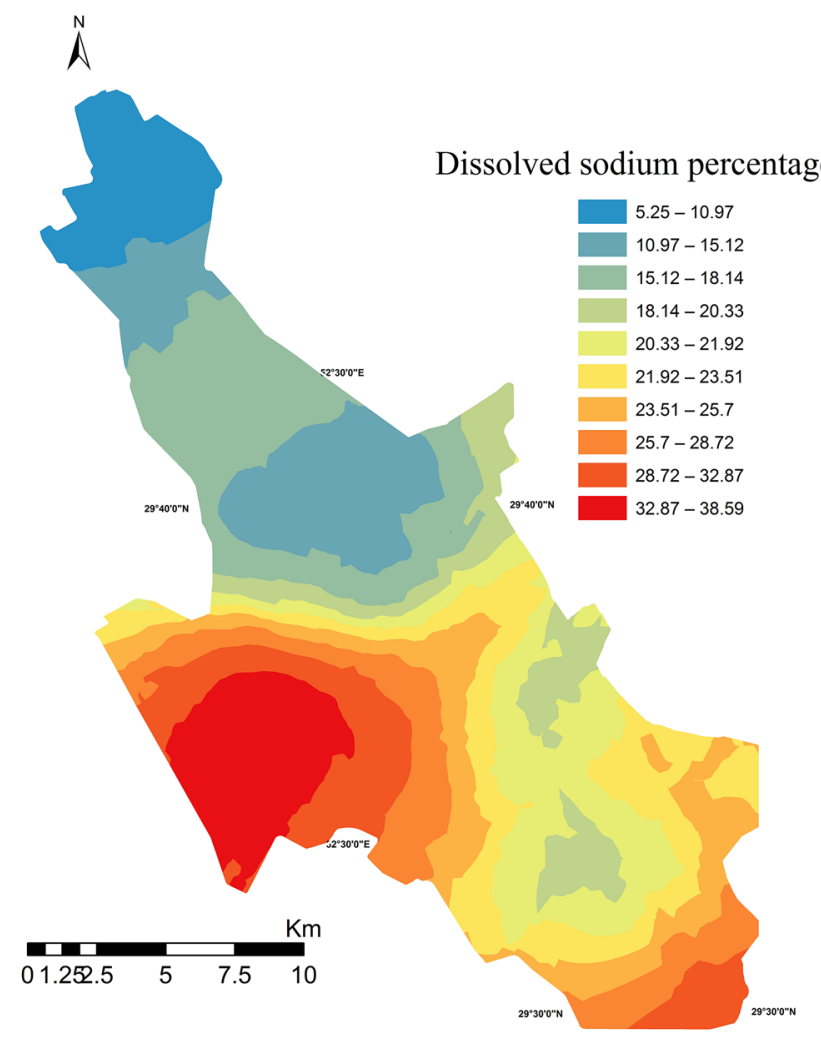

Fig. 2 (continued)

$$
S A R=\frac{\mathrm{Na}^{+}}{\sqrt{\frac{\mathrm{Ca}^{2+}+\mathrm{Mg}^{2+}}{2}}}
$$

SAR levels were presented in $\mathrm{meq} / \mathrm{L}$ and varied from 0.21 to 6.64 with mean value of 1.76. SAR values were found below $<10$, belongs to excellent category. Richards [45] suggested following grades to classify the SAR: $<10$ : excellent, 18: good, 18-26: doubtful and > 26: unsuitable. The skewness and kurtosis of SAR values were also recorded greater than one indicating right handed skewness and leptokurtic [38]. SAR values for all the samples were excellent for irrigation and agricultural practices. Figure 2 presents the spatial distribution of SAR values for the present study on the basis of kriging approach.

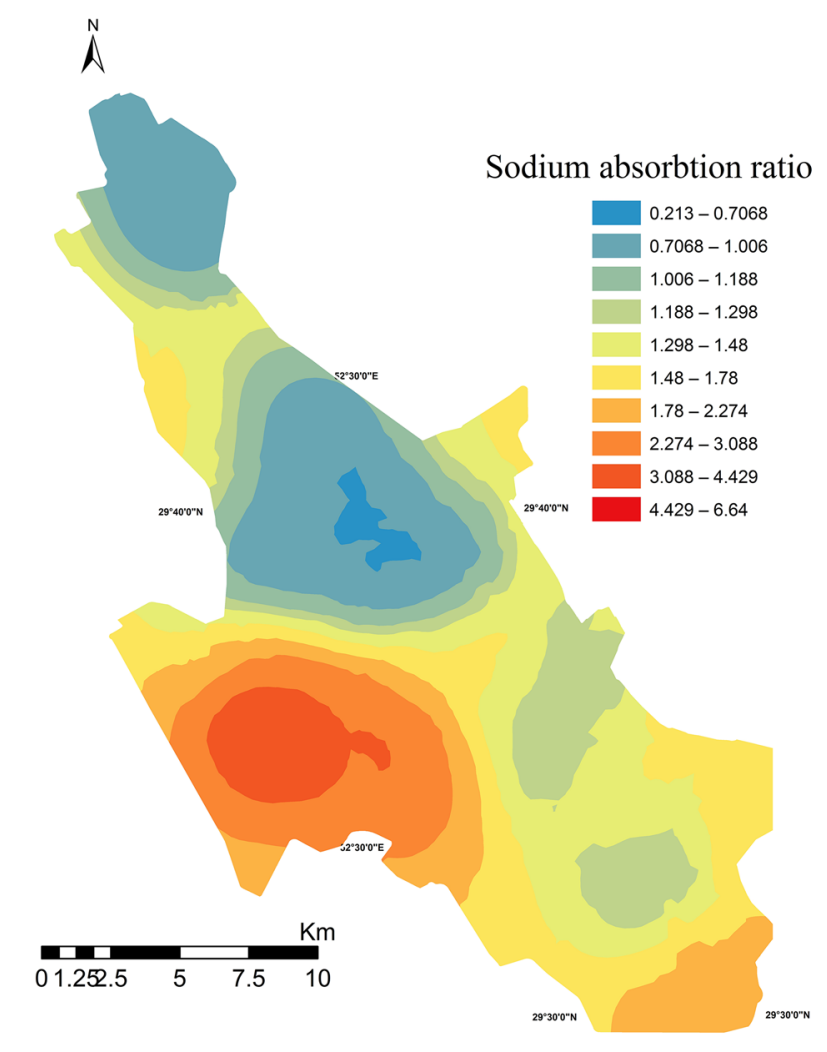

\subsection{Base-exchange indices (BEI) and meteoric genesis indices (MGI)}

The BEI and MGI were determined by following Matthess [46], Soltan $[47,48]$ and are calculated by following equations:

$B E I=\frac{\mathrm{Na}^{+}-\mathrm{Cl}^{-}}{\mathrm{SO}_{4}{ }^{2-}}$

$M G I=\frac{\left[\left(\mathrm{Na}^{+}+\mathrm{K}^{+}\right)-\mathrm{Cl}^{-}\right]}{\mathrm{SO}_{4}{ }^{2-}}$

On the basis of these indices, groundwater is grouped as: $\mathrm{Na}^{+}-\mathrm{HCO}_{3}{ }^{-}$type if $\mathrm{BEI}>1$ and $\mathrm{Na}^{+}-\mathrm{SO}_{4}{ }^{2-}$ type if $\mathrm{BEI}<1$. 
Fig. 3 Pearson's correlation analysis of groundwater parameters

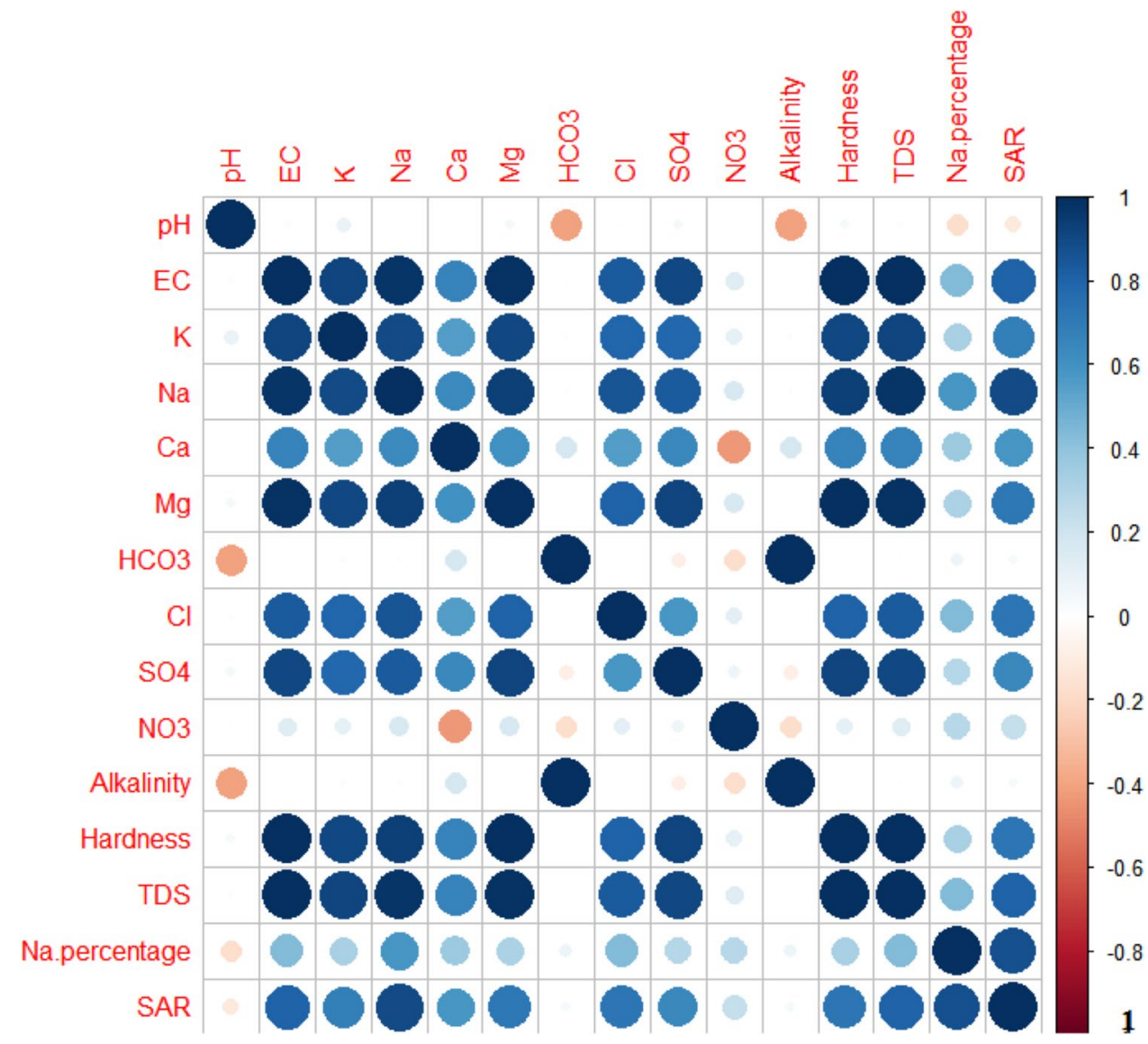

If $M G l<1$, then water type is of deep meteoric type and if $M G I>1$, the it is of shallow meteoric percolation type. The results of $\mathrm{BEI}$ and $\mathrm{MGI}$ are presented in Table 2. From the results of $\mathrm{MGl}$, it was found that $83.75 \%$ sampling sites showed shallow meteoric percolation type, while $16.25 \%$ sampling sites indicated deep meteoric percolation type. $83.75 \%$ sampling sites showed $\mathrm{BEI}$ values less than one and indicated $\mathrm{Na}+\mathrm{SO}_{4}$, while $16.25 \%$ sampling sites showed $\mathrm{Na}+\mathrm{HCO}_{3}$ water type.

\subsection{Multivariate statistical analysis of groundwater parameters}

Cluster analysis ( $C A$ ) was prepared to classify the different parameters (Fig. 4). CA mainly categorized the groundwater parameters into two groups such as alkalinity and $\mathrm{HCO}_{3}{ }^{-}$in one group and rest of the parameters are included in other cluster which is further grouped into two subgroups: subgroup I $\left(\mathrm{NO}_{3}{ }^{-}, \mathrm{pH}, \mathrm{Na} \%\right.$ and $\left.\mathrm{SAR}\right)$ and subgroup II (EC, TDS, $\mathrm{Ca}^{2+}, \mathrm{Na}^{+}, \mathrm{Mg}^{2+}, \mathrm{SO}_{4}{ }^{2-}, \mathrm{Cl}^{-}$, hardness and $K$ ).

CA was also prepared for different sampling sites on the basis of groundwater parameters (Fig. 5). Mainly three clusters were formed for sampling sites which are further categorized into subgroups. Cluster 1 comprises of sites (1, $24,13,2,8,5,45,53,74,78,6,19,77,60,76,11,14,25,9$, $18,17,20,10,23,26,15,16$ and 21$)$ which is categorized in four sub-clusters $(1,24,13,2$ and 8$),(5,45,53,74$ and 78$)$, $(6,19,77,60,76,11,14$ and 25$)$, and $(9,18,17,20,10,23$, 26,15 and 16). Site 21 formed a separate cluster 2 which may be attributed to high $\mathrm{Na}, \mathrm{K}, \mathrm{Cl}, \mathrm{SO}_{4}$, hardness and alkalinity of the groundwater. Rock containing minerals are responsible for the contribution of these parameters in the area. Cluster 3 comprises of three sub-groups: $(3,12,36$, 
Table 2 Groundwater classification according to base-exchange index (BGI) and meteoric genesis index (MGI) criteria

\begin{tabular}{|c|c|c|c|c|}
\hline $\begin{array}{l}\text { Sampling } \\
\text { sites }\end{array}$ & BEI & Water type & MGI & Water type \\
\hline 1 & -0.14 & $\mathrm{Na}+\mathrm{SO}_{4}$ & 0.28 & Shallow meteoric \\
\hline 2 & -0.05 & $\mathrm{Na}+\mathrm{SO}_{4}$ & 0.37 & Shallow meteoric \\
\hline 3 & -1.74 & $\mathrm{Na}+\mathrm{HCO}_{3}$ & -0.42 & Deep meteoric \\
\hline 4 & -30.96 & $\mathrm{Na}+\mathrm{HCO}_{3}$ & 3.98 & Shallow meteoric \\
\hline 5 & -1.02 & $\mathrm{Na}+\mathrm{HCO}_{3}$ & 0.16 & Shallow meteoric \\
\hline 6 & -0.13 & $\mathrm{Na}+\mathrm{SO}_{4}$ & 0.65 & Shallow meteoric \\
\hline 7 & -0.23 & $\mathrm{Na}+\mathrm{SO}_{4}$ & 0.74 & Shallow meteoric \\
\hline 8 & -0.08 & $\mathrm{Na}+\mathrm{SO}_{4}$ & 0.28 & Shallow meteoric \\
\hline 9 & -0.07 & $\mathrm{Na}+\mathrm{SO}_{4}$ & 0.22 & Shallow meteoric \\
\hline 10 & -2.83 & $\mathrm{Na}+\mathrm{HCO}_{3}$ & -1.08 & Deep meteoric \\
\hline 11 & 0.09 & $\mathrm{Na}+\mathrm{HCO}_{3}$ & 0.61 & Shallow meteoric \\
\hline 12 & -3.96 & $\mathrm{Na}+\mathrm{HCO}_{3}$ & 4.43 & Shallow meteoric \\
\hline 13 & -0.22 & $\mathrm{Na}+\mathrm{SO}_{4}$ & 0.26 & Shallow meteoric \\
\hline 14 & -1.16 & $\mathrm{Na}+\mathrm{HCO}_{3}$ & -0.004 & Deep meteoric \\
\hline 15 & -1.89 & $\mathrm{Na}+\mathrm{HCO}_{3}$ & -0.86 & Deep meteoric \\
\hline 16 & -5.86 & $\mathrm{Na}+\mathrm{HCO}_{3}$ & -0.98 & Deep meteoric \\
\hline 17 & -0.52 & $\mathrm{Na}+\mathrm{SO}_{4}$ & 0.06 & Shallow meteoric \\
\hline 18 & -0.25 & $\mathrm{Na}+\mathrm{SO}_{4}$ & 0.56 & Shallow meteoric \\
\hline 19 & -0.27 & $\mathrm{Na}+\mathrm{SO}_{4}$ & 0.42 & Shallow meteoric \\
\hline 20 & -0.57 & $\mathrm{Na}+\mathrm{SO}_{4}$ & 2.08 & Shallow meteoric \\
\hline 21 & -0.53 & $\mathrm{Na}+\mathrm{SO}_{4}$ & 0.67 & Shallow meteoric \\
\hline 22 & -0.19 & $\mathrm{Na}+\mathrm{SO}_{4}$ & 1.92 & Shallow meteoric \\
\hline 23 & -0.80 & $\mathrm{Na}+\mathrm{SO}_{4}$ & -0.20 & Deep meteoric \\
\hline 24 & -0.04 & $\mathrm{Na}+\mathrm{SO}_{4}$ & 0.36 & Shallow meteoric \\
\hline 25 & -0.27 & $\mathrm{Na}+\mathrm{SO}_{4}$ & 0.61 & Shallow meteoric \\
\hline 26 & -2.11 & $\mathrm{Na}+\mathrm{HCO}_{3}$ & -0.73 & Deep meteoric \\
\hline 27 & -0.82 & $\mathrm{Na}+\mathrm{SO}_{4}$ & 0.22 & Shallow meteoric \\
\hline 28 & -0.16 & $\mathrm{Na}+\mathrm{SO}_{4}$ & 0.53 & Shallow meteoric \\
\hline 29 & -0.11 & $\mathrm{Na}+\mathrm{SO}_{4}$ & 0.45 & Shallow meteoric \\
\hline 30 & -0.02 & $\mathrm{Na}+\mathrm{SO}_{4}$ & 0.69 & Shallow meteoric \\
\hline 31 & -0.50 & $\mathrm{Na}+\mathrm{SO}_{4}$ & 0.17 & Shallow meteoric \\
\hline 32 & -0.87 & $\mathrm{Na}+\mathrm{SO}_{4}$ & 0.27 & Shallow meteoric \\
\hline 33 & -0.12 & $\mathrm{Na}+\mathrm{SO}_{4}$ & 2.47 & Shallow meteoric \\
\hline 34 & -0.56 & $\mathrm{Na}+\mathrm{SO}_{4}$ & 0.25 & Shallow meteoric \\
\hline 35 & -0.87 & $\mathrm{Na}+\mathrm{SO}_{4}$ & 0.23 & Shallow meteoric \\
\hline 36 & -0.74 & $\mathrm{Na}+\mathrm{SO}_{4}$ & -0.05 & Deep meteoric \\
\hline 37 & -0.72 & $\mathrm{Na}+\mathrm{SO}_{4}$ & -0.16 & Deep meteoric \\
\hline 38 & -0.43 & $\mathrm{Na}+\mathrm{SO}_{4}$ & 1.01 & Shallow meteoric \\
\hline 39 & -0.34 & $\mathrm{Na}+\mathrm{SO}_{4}$ & 0.25 & Shallow meteoric \\
\hline 40 & -0.06 & $\mathrm{Na}+\mathrm{SO}_{4}$ & 0.28 & Shallow meteoric \\
\hline 41 & -0.45 & $\mathrm{Na}+\mathrm{SO}_{4}$ & 0.21 & Shallow meteoric \\
\hline 42 & -1.12 & $\mathrm{Na}+\mathrm{HCO}_{3}$ & 0.58 & Shallow meteoric \\
\hline 43 & -0.81 & $\mathrm{Na}+\mathrm{SO}_{4}$ & 0.27 & Shallow meteoric \\
\hline 44 & -0.53 & $\mathrm{Na}+\mathrm{SO}_{4}$ & 0.12 & Shallow meteoric \\
\hline 45 & -0.61 & $\mathrm{Na}+\mathrm{SO}_{4}$ & -0.06 & Deep meteoric \\
\hline 46 & -0.20 & $\mathrm{Na}+\mathrm{SO}_{4}$ & 0.07 & Shallow meteoric \\
\hline 47 & -0.24 & $\mathrm{Na}+\mathrm{SO}_{4}$ & 0.72 & Shallow meteoric \\
\hline 48 & -0.59 & $\mathrm{Na}+\mathrm{SO}_{4}$ & -0.05 & Deep meteoric \\
\hline
\end{tabular}

Table 2 (continued)

\begin{tabular}{lllll}
\hline Sampling & \multicolumn{1}{l}{$\mathrm{BEI}$} & $\mathrm{Water}$ type & \multicolumn{1}{l}{$\mathrm{MGl}$} & Water type \\
sites & & & & \\
\hline 49 & -0.32 & $\mathrm{Na}+\mathrm{SO}_{4}$ & 0.60 & Shallow meteoric \\
50 & -0.13 & $\mathrm{Na}+\mathrm{SO}_{4}$ & 0.70 & Shallow meteoric \\
51 & -0.16 & $\mathrm{Na}+\mathrm{SO}_{4}$ & 0.39 & Shallow meteoric \\
52 & -0.34 & $\mathrm{Na}+\mathrm{SO}_{4}$ & 0.63 & Shallow meteoric \\
53 & -0.37 & $\mathrm{Na}+\mathrm{SO}_{4}$ & 0.38 & Shallow meteoric \\
54 & -0.89 & $\mathrm{Na}+\mathrm{SO}_{4}$ & 0.04 & Shallow meteoric \\
55 & -0.18 & $\mathrm{Na}+\mathrm{SO}_{4}$ & 0.74 & Shallow meteoric \\
56 & -0.23 & $\mathrm{Na}+\mathrm{SO}_{4}$ & 0.58 & Shallow meteoric \\
57 & -0.34 & $\mathrm{Na}+\mathrm{SO}_{4}$ & 0.78 & Shallow meteoric \\
58 & -0.13 & $\mathrm{Na}+\mathrm{SO}_{4}$ & 0.50 & Shallow meteoric \\
59 & -0.56 & $\mathrm{Na}+\mathrm{SO}_{4}$ & 0.32 & Shallow meteoric \\
60 & -0.18 & $\mathrm{Na}+\mathrm{SO}_{4}$ & 0.38 & Shallow meteoric \\
61 & -0.14 & $\mathrm{Na}+\mathrm{SO}_{4}$ & -0.02 & Deep meteoric \\
62 & -4.26 & $\mathrm{Na}+\mathrm{HCO}_{3}$ & -3.92 & Deep meteoric \\
63 & -0.34 & $\mathrm{Na}+\mathrm{SO}_{4}$ & 0.10 & Shallow meteoric \\
64 & -0.32 & $\mathrm{Na}+\mathrm{SO}_{4}$ & 0.26 & Shallow meteoric \\
65 & -0.22 & $\mathrm{Na}+\mathrm{SO}_{4}$ & 0.78 & Shallow meteoric \\
66 & -0.40 & $\mathrm{Na}+\mathrm{SO}_{4}$ & 0.23 & Shallow meteoric \\
67 & -0.28 & $\mathrm{Na}+\mathrm{SO}_{4}$ & 0.26 & Shallow meteoric \\
68 & -0.78 & $\mathrm{Na}+\mathrm{SO}_{4}$ & -0.13 & Shallow meteoric \\
69 & -0.64 & $\mathrm{Na}+\mathrm{SO}_{4}$ & 3.60 & Shallow meteoric \\
70 & -0.49 & $\mathrm{Na}+\mathrm{SO}_{4}$ & 1.38 & Shallow meteoric \\
71 & -0.07 & $\mathrm{Na}+\mathrm{SO}_{4}$ & 0.52 & Shallow meteoric \\
72 & -2.30 & $\mathrm{Na}+\mathrm{HCO}_{3}$ & 1.22 & Shallow meteoric \\
73 & -0.01 & $\mathrm{Na}+\mathrm{SO}_{4}$ & 0.69 & Shallow meteoric \\
74 & -0.32 & $\mathrm{Na}+\mathrm{SO}_{4}$ & 0.54 & Shallow meteoric \\
75 & -0.11 & $\mathrm{Na}+\mathrm{SO}_{4}$ & 0.56 & Shallow meteoric \\
76 & -0.25 & $\mathrm{Na}+\mathrm{SO}_{4}$ & 0.18 & Shallow meteoric \\
& -0.22 & $\mathrm{Na}+\mathrm{SO}_{4}$ & 0.46 & Shallow meteoric \\
75 & $\mathrm{Na}+\mathrm{SO}_{4}$ & 0.26 & Shallow meteoric \\
& $\mathrm{Na}+\mathrm{SO}_{4}$ & 0.24 & Shallow meteoric \\
\hline 5 & $\mathrm{Na}+\mathrm{SO}_{4}$ & 0.31 & Shallow meteoric \\
\hline 5 & & &
\end{tabular}

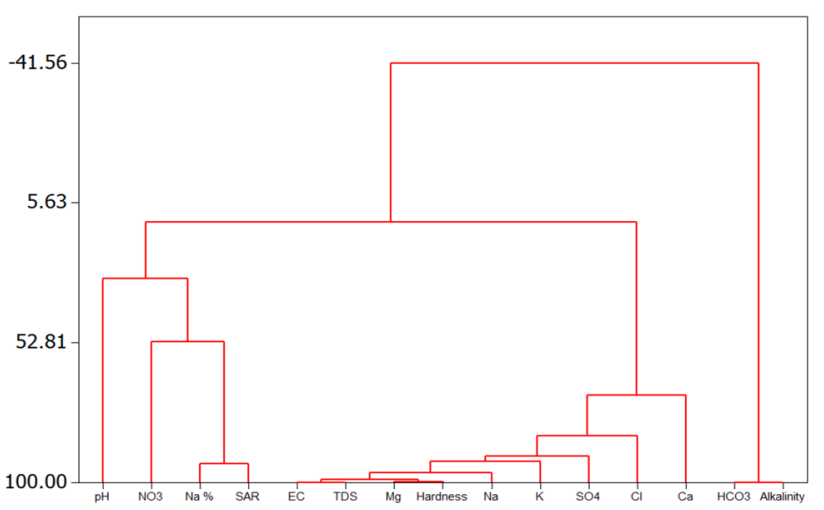

Fig. 4 Cluster analysis of groundwater parameters 
Fig. 5 Cluster analysis of sampling sites
C A S E Label Num +

39

66

32
42

33

54

4
38
47

47
72
61

61
67

29

51
56
57
37

37
63
31

31

31
34
44

44
68
46

46

43

48

28
58

58
79

79
12

36
3

3
59

80

40
22
69

22

65

65
70

27

41

49

55
64

64
75

73

50
52

52
7
30

30
62

62
2

2
8
1

1
24
13

13
53

74

45

78
5

60
76

76
77

6
11

14

25
15

15
16
23

23

26
10

9
18

18
17

20

21

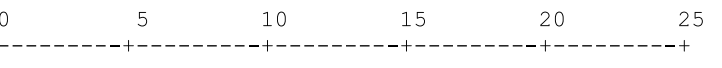
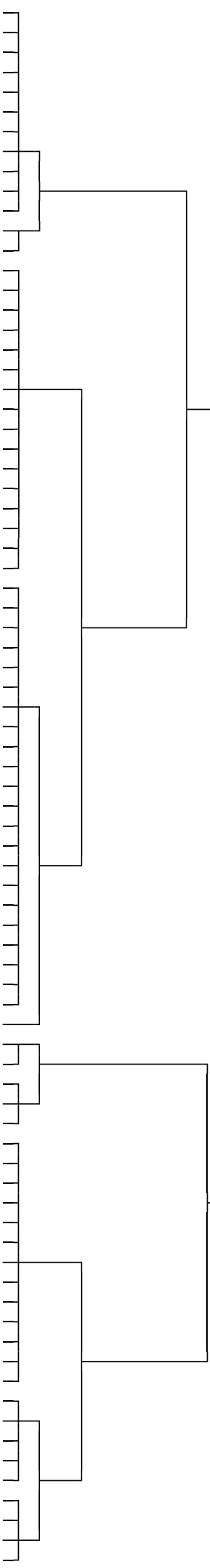


\begin{tabular}{|c|c|c|c|c|c|c|c|}
\hline$\underset{\leftarrow}{\mathfrak{c}}$ & 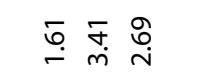 & 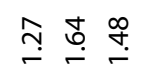 & $\stackrel{a}{\grave{i}} \stackrel{\frac{n}{m}}{\stackrel{a}{\grave{i}}}$ & 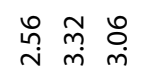 & $\begin{array}{l}\overline{0} \\
0\end{array}$ & 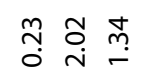 & ป. 学 $\stackrel{\infty}{=}$ \\
\hline $\begin{array}{l}\frac{9}{2} \\
\frac{\pi}{2}\end{array}$ & 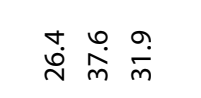 & 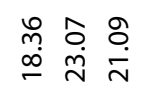 & 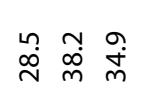 & 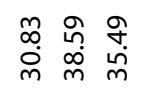 & 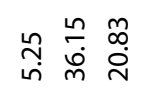 & 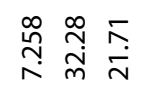 & 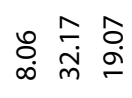 \\
\hline 气 & 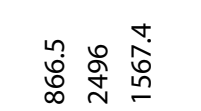 & 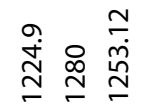 & 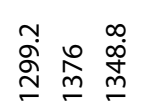 & 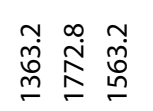 & 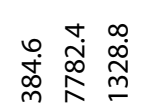 & 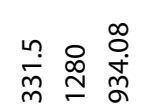 & 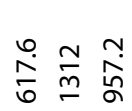 \\
\hline के & 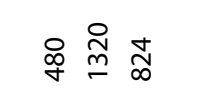 & 옥 \& & 员 员 & గ్రి సิ ฉ & 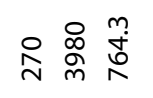 & $\stackrel{\otimes}{\sim} \underset{\infty}{-\infty}$ & 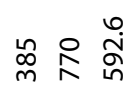 \\
\hline है & 요 & 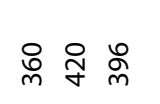 & 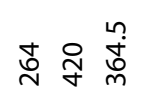 & 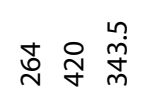 & 守 方 $\stackrel{m}{n}$ & $\exists \underset{\sim}{\tilde{F}} \stackrel{\sim}{\infty}$ & 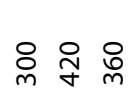 \\
\hline 'ं & 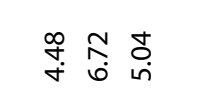 & กุ & 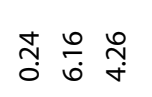 & 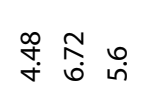 & $\stackrel{0}{\circ} \stackrel{m}{\sim} \stackrel{⿱ 亠 ⿻}{\sim}$ & 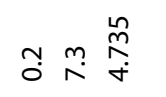 & 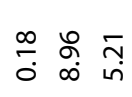 \\
\hline 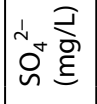 & 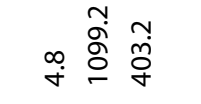 & 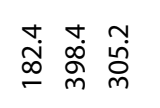 & 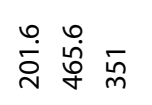 & 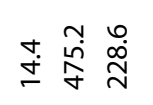 & 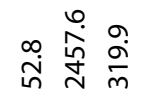 & 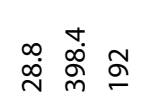 & 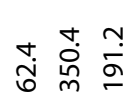 \\
\hline$\frac{5}{5}$ & 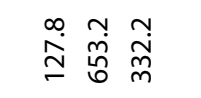 & 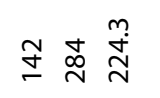 & 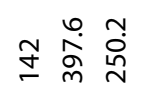 & 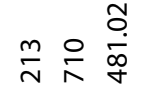 & 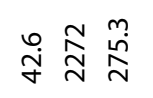 & 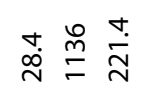 & 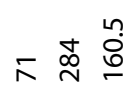 \\
\hline 乌े & 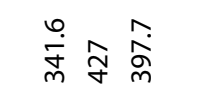 & 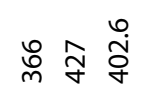 & 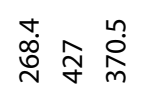 & 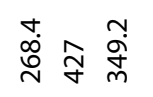 & 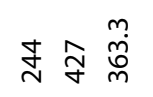 & 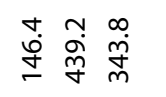 & 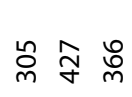 \\
\hline ثे & 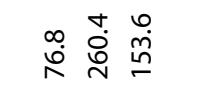 & 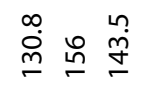 & 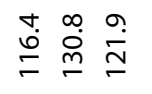 & 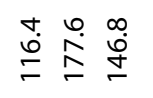 & 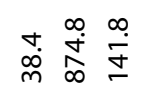 & 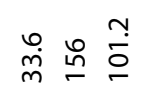 & i̊ \\
\hline 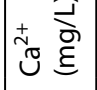 & 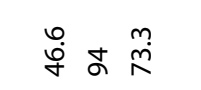 & นn & તี & チ & 움 & 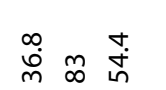 & $\stackrel{+}{\infty} \bar{m} \bar{\infty} \bar{i}$ \\
\hline $\begin{array}{l}\xi \\
+ \\
\frac{\pi}{2}\end{array}$ & 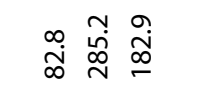 & 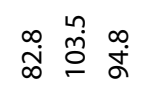 & 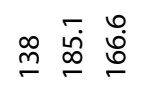 & 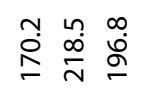 & 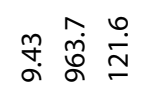 & 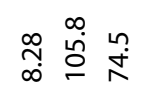 & 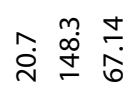 \\
\hline 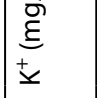 & 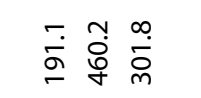 & のે ণ্ণ & 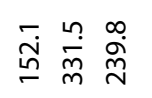 & 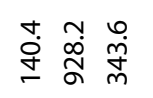 & 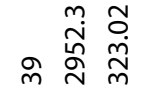 & 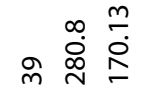 & ㄲ. \\
\hline 冡 & 芯 \& & 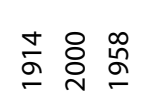 & 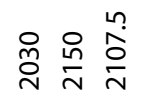 & 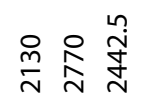 & 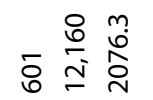 & 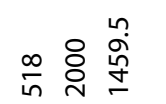 & 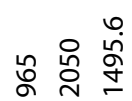 \\
\hline$\frac{T}{Q}$ & 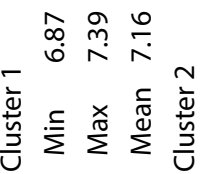 & 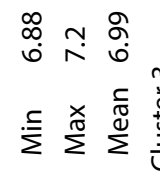 & 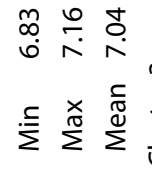 & 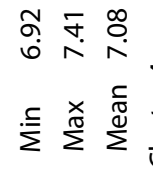 & 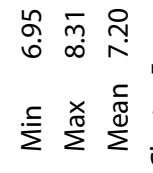 & 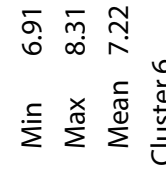 & 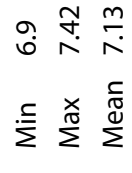 \\
\hline
\end{tabular}


Table 4 Principal component analysis of groundwater parameters

\begin{tabular}{|c|c|c|c|c|c|c|c|c|c|}
\hline \multirow[t]{2}{*}{ Component } & \multicolumn{3}{|c|}{ Initial eigen values } & \multicolumn{3}{|c|}{ Extraction sums of squared loadings } & \multicolumn{3}{|c|}{ Rotation sums of squared loadings } \\
\hline & Total & $\%$ of Variance & Cumulative $\%$ & Total & $\%$ of Variance & Cumulative\% & Total & $\%$ of Variance & Cumulative $\%$ \\
\hline 1 & 9.72 & 64.8 & 64.8 & 9.72 & 64.8 & 64.8 & 9.70 & 64.7 & 64.7 \\
\hline 2 & 2.36 & 15.7 & 80.5 & 2.36 & 15.7 & 80.5 & 2.26 & 15.0 & 79.7 \\
\hline 3 & 1.27 & 8.4 & 89.0 & 1.27 & 8.4 & 89.0 & 1.39 & 9.2 & 89.0 \\
\hline \multirow{2}{*}{\multicolumn{2}{|c|}{ Variables }} & \multicolumn{3}{|c|}{ Component matrix } & \multirow{2}{*}{\multicolumn{2}{|c|}{ Variables }} & \multicolumn{3}{|c|}{ Rotated component matrix } \\
\hline & & PC1 & PC2 & PC3 & & & PC1 & PC2 & PC3 \\
\hline \multicolumn{2}{|l|}{$\mathrm{pH}$} & 0.027 & -0.571 & -0.367 & \multicolumn{2}{|l|}{$\mathrm{pH}$} & 0.018 & -0.655 & 0.176 \\
\hline \multicolumn{2}{|l|}{$\mathrm{EC}(\mu \mathrm{S} / \mathrm{cm})$} & 0.997 & -0.007 & 0.039 & \multicolumn{2}{|c|}{$\mathrm{EC}(\mu \mathrm{S} / \mathrm{cm})$} & 0.998 & 0.004 & 0.008 \\
\hline \multicolumn{2}{|l|}{$\mathrm{K}^{+}(\mathrm{mg} / \mathrm{L})$} & 0.923 & -0.044 & 0.029 & \multicolumn{2}{|c|}{$\mathrm{K}^{+}(\mathrm{mg} / \mathrm{L})$} & 0.924 & -0.034 & 0.003 \\
\hline \multicolumn{2}{|l|}{$\mathrm{Na}^{+}(\mathrm{mg} / \mathrm{L})$} & 0.970 & -0.002 & 0.081 & \multicolumn{2}{|c|}{$\mathrm{Na}^{+}(\mathrm{mg} / \mathrm{L})$} & 0.973 & 0.022 & -0.032 \\
\hline \multicolumn{2}{|l|}{$\mathrm{Ca}^{2+}(\mathrm{mg} / \mathrm{L})$} & 0.693 & 0.276 & -0.544 & \multicolumn{2}{|c|}{$\mathrm{Ca}^{2+}(\mathrm{mg} / \mathrm{L})$} & 0.664 & 0.096 & 0.635 \\
\hline \multicolumn{2}{|l|}{$\mathrm{Mg}^{2+}(\mathrm{mg} / \mathrm{L})$} & 0.982 & -0.037 & 0.069 & \multicolumn{2}{|c|}{$\mathrm{Mg}^{2+}(\mathrm{mg} / \mathrm{L})$} & 0.985 & -0.015 & -0.030 \\
\hline \multicolumn{2}{|l|}{$\mathrm{HCO}_{3}^{-}(\mathrm{mg} / \mathrm{L})$} & 0.008 & 0.956 & 0.128 & \multicolumn{2}{|c|}{$\mathrm{HCO}_{3}{ }^{-}(\mathrm{mg} / \mathrm{L})$} & 0.001 & 0.950 & 0.171 \\
\hline \multicolumn{2}{|l|}{$\mathrm{Cl}^{-}(\mathrm{mg} / \mathrm{L})$} & 0.858 & -0.007 & 0.064 & \multicolumn{2}{|c|}{$\mathrm{Cl}^{-}(\mathrm{mg} / \mathrm{L})$} & 0.860 & 0.012 & -0.022 \\
\hline \multicolumn{2}{|l|}{$\mathrm{SO}_{4}{ }^{2-}(\mathrm{mg} / \mathrm{L})$} & 0.899 & -0.084 & -0.072 & \multicolumn{2}{|c|}{$\mathrm{SO}_{4}{ }^{2-}(\mathrm{mg} / \mathrm{L})$} & 0.896 & -0.103 & 0.086 \\
\hline \multicolumn{2}{|l|}{$\mathrm{NO}_{3}^{-}(\mathrm{mg} / \mathrm{L})$} & 0.100 & -0.344 & 0.885 & \multicolumn{2}{|c|}{$\mathrm{NO}_{3}^{-}(\mathrm{mg} / \mathrm{L})$} & 0.145 & -0.058 & -0.942 \\
\hline \multicolumn{2}{|l|}{ Alkalinity (mg/L) } & 0.008 & 0.956 & 0.128 & \multicolumn{2}{|c|}{ Alkalinity (mg/L) } & 0.001 & 0.950 & 0.171 \\
\hline \multicolumn{2}{|c|}{ Hardness (mg/L) } & 0.989 & -0.005 & 0.008 & \multicolumn{2}{|c|}{ Hardness (mg/L) } & 0.989 & -0.004 & 0.037 \\
\hline \multicolumn{2}{|l|}{ TDS (mg/L) } & 0.997 & -0.007 & 0.039 & \multicolumn{2}{|c|}{ TDS (mg/L) } & 0.998 & 0.004 & 0.008 \\
\hline
\end{tabular}

Bold letter indicates significant laodings in the PCs

$40,50,80,71,7,30,50,52,64,75,73,27,41,49,55,65,70$, $22,69$ and 62$),(28,58,79,43,48,44,68,46,29,51,31,37$, $63,34,56$ and 57$)$, and $(4,32,42,33,39,66,35,54,38,47$, $72,61$ and 67$)$. From the results of $C A$, it was established that combined anthropogenic activities like cement factory, gas power plant, Rishmark factory and vegetable Oil Company, and natural processes like rock weathering are responsible for the source apportionment of groundwater parameters. The content of various physicochemical parameters of groundwater for six clusters are presented in Table 3. Cluster 1 showed high content of $\mathrm{EC}, \mathrm{Ca}^{2+}$, $\mathrm{Mg}^{2+}, \mathrm{SO}_{4}{ }^{2-}$ and hardness. Cluster 2 is dominated by high content of alkalinity and $\mathrm{HCO}_{3}{ }^{-}$. Cluster 3 is contributed by high concentrations of $\mathrm{K}^{+}, \mathrm{Na}^{+}, \mathrm{Na}(\%)$ and $\mathrm{SAR}$, while cluster 4 is dominated by $\mathrm{Cl}^{-}$and $\mathrm{NO}_{3}{ }^{-}$. Among the entire parameters cluster 5 is controlled mainly by $\mathrm{pH}$. Cluster 6 showed alterations in the content of all the parameters.

Principal component analysis (PCA) was applied to the groundwater parameters (Table 4). The first three PCs accounted for $89 \%$ of the total variation. Three components were extracted on the basis of eigenvalues of more than one [49]. The loadings of the PCs in the component matrix explained that $\mathrm{PC} 1$ had maximum loadings on $\mathrm{EC}, \mathrm{K}^{+}, \mathrm{Na}^{+}, \mathrm{Ca}^{2+}, \mathrm{Mg}^{2+}, \mathrm{Cl}^{-}, \mathrm{SO}_{4}{ }^{2-}$, hardness and TDS, and accounted for $64.8 \%$ of the variation. EC and TDS loadings control the overall mineralization. Loading of Ca may be ascribed to its usage in the cement factory located in the study area. $\mathrm{K}^{+}$and $\mathrm{Na}^{+}$are generally contributed by rocks and anthropogenic sources. $\mathrm{Cl}^{-}$containing minerals contributes $\mathrm{Cl}^{-}$content in the groundwater [50]. Atmospheric deposition and power plants contributes $\mathrm{SO}_{4}{ }^{2-}$ content in the area [51]. Hardness occurs due to chemical and mining industry wastage or high usage of lime. The PC1 is mainly contributed by anthropogenic activities, i.e., cement factory, gas power plant, Rishmark factory and vegetable Oil Company existed in the Shiraz city as well as natural processes. $15.7 \%$ of the variation explained by the PC2 and have maximum loadings on $\mathrm{HCO}_{3}{ }^{-}$and alkalinity. The $\mathrm{HCO}_{3}{ }^{-}$and alkalinity are contributed mainly by rock sources to this $\mathrm{PC} . \mathrm{NO}_{3}{ }^{-}$had maximum loading on $\mathrm{PC} 3$ and accounted for $8.4 \%$ of the variance. The application of agricultural fertilizers contributes to this PC. The similar type of loadings was obtained for different groundwater parameters after varimax rotation. Selvakumar et al. [52] in their studies on groundwater in Tamil Nadu, India reported loadings of $\mathrm{EC}, \mathrm{Ca}^{2+}, \mathrm{Mg}^{2+}, \mathrm{Na}^{+}, \mathrm{K}^{+}$and $\mathrm{Cl}^{-}$on $\mathrm{PC} 1$ which supports our results. Our results find support from Ravikumar and Somashekar [53] in their research on groundwater of Karnataka and reported loadings of EC, TDS, hardness, $\mathrm{Ca}^{2+}, \mathrm{Mg}^{2+}, \mathrm{K}^{+}, \mathrm{HCO}_{3}{ }^{-}$, $\mathrm{SO}_{4}{ }^{2-}$ and $\mathrm{Cl}^{-}$on $\mathrm{PC} 1$. Non-metric multidimensional scaling (NMDS) was done on 80 different sampling sites on the basis of groundwater parameters. Correlation was 

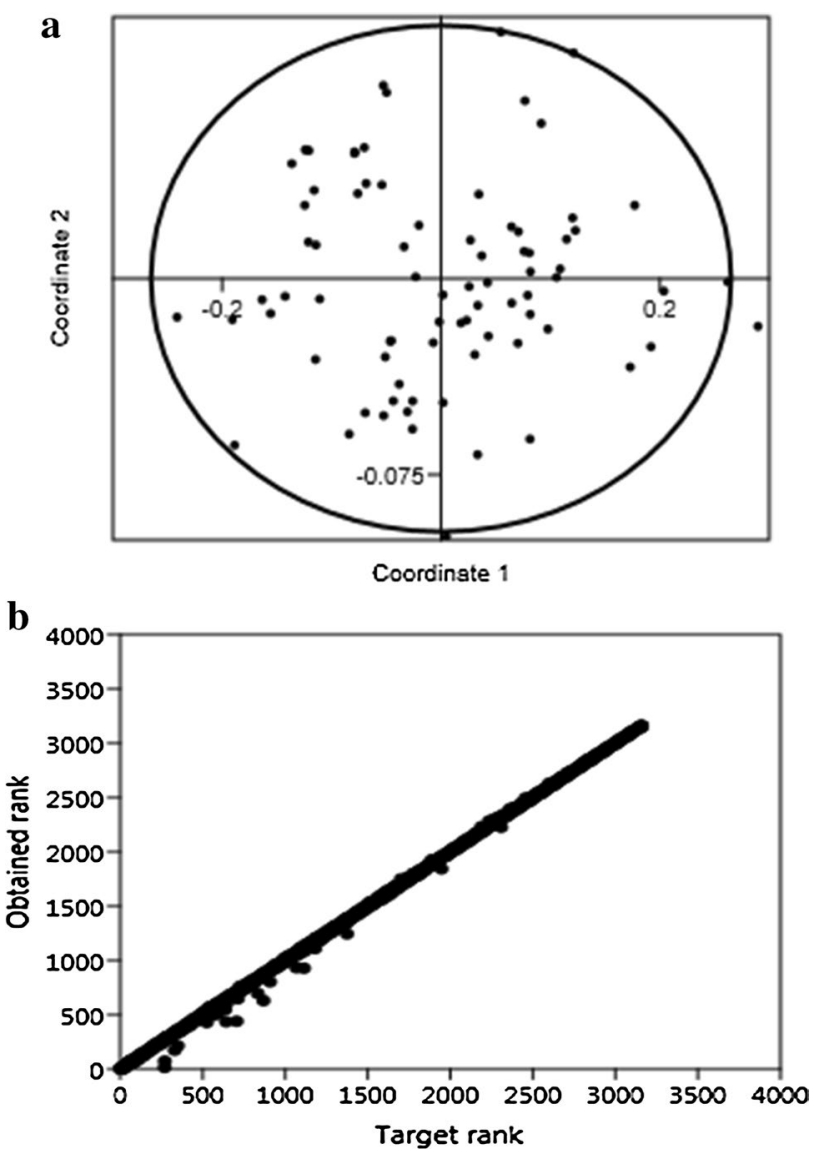

Fig. 6 a NMDS scatter plot (95\% ecclipse) of groundwater parameters using correlation, b NMDS Shepard 2-D plot of groundwater parameters

used as the similarity measure. NMDS is a nonparametric multivariate technique. The ranks were compressed in two dimensions. NMDS scatter plot and Shepard plot for the sampling sites are presented in Fig. 6a, b. Shepard plot indicated a stress level of 0.0078. A stress level less than 0.05 is a good fit of the data. The stress level formed in NMDS showed that levels of sampling points are maintained on data compression, indicating that differences in the sampling points are dependable on groundwater quality parameters.

\section{Conclusion}

The study area comprised of surface unconstrained to deep aquifers. Due to shallow water table groundwater may become susceptible to discharge of pollutants from the surface, and about 80 samples were collected and analyzed for various physiochemical parameters. The mean values of $\mathrm{EC}, \mathrm{K}^{+}, \mathrm{Mg}^{2+}, \mathrm{SO}_{4}{ }^{2-}$ and TDS were found above the permissible limits of WHO for drinking water. $97.5 \%$ samples for hardness were falls in the category of $>300$, indicating very hard water. SAR and $\mathrm{Na} \%$ results indicated that water is acceptable for irrigation as well as domestic purposes. The MGI results indicated that $83.75 \%$ sampling sites showed shallow meteoric percolation type, whereas $16.25 \%$ sampling sites showed deep meteoric percolation type. $83.75 \%$ sampling sites showed BEI values less than one, while $16.25 \%$ sampling sites showed $B E I$ values greater than one showing $\mathrm{Na}+\mathrm{HCO}_{3}$ water type. Multivariate statistical analysis (CA \& PCA) showed that both anthropogenic activities such as cement factory, gas power plant, Rishmark factory and vegetable Oil Company, and natural processes like rock weathering are responsible for the contents of groundwater parameters.

\section{Compliance with ethical standards}

Conflict of interest Authors declared that there is no conflict of interest.

\section{References}

1. Harvey CF, Swartz CH, Badruzzaman AB, Keon-Blute N, Yu W, Ali MA, Jay J, Beckie R, Niedan V, Brabander D, Oates PM (2002) Arsenic mobility and groundwater extraction in Bangladesh. Science 298(5598):1602-1606

2. Singh KP, Malik A, Mohan D, Sinha S (2004) Multivariate statistical techniques for the evaluation of spatial and temporal variations in water quality of Gomti River (India) - a case study. Water Res 38(18):3980-3992

3. Baba A, Tayfur G (2011) Groundwater contamination and its effect on health in Turkey. Environ Monit Assess 183(1-4):77-94

4. Jones F, Watkins J (1985) The water cycle as a source of pathogens. J Appl Bacteriol 59:27S-36S

5. Nash H, McCall GJH (1995) Groundwater quality. In: 17th Special Report. Chapman and Hall, London

6. Moosavirad SM, Janardhana MR, Khairy H (2013) Impact of anthropogenic activities on the chemistry and quality of groundwater: a case study from a terrain near Zarand City, Kerman Province, SE Iran. Environ Earth Sci 69(7):2451-2467

7. Mirlas V, Antonenko V, Kulagin V, Kuldeeva E (2015) Assessing artificial groundwater recharge on irrigated land using the MODFLOW model: a case study from Karatal agricultural area, Kazakhstan. Earth Sci Res 4(2):16

8. Alberti L, Colombo L, Formentin G (2018) Null-space Monte Carlo particle tracking to assess groundwater PCE (Tetrachloroethene) diffuse pollution in north-eastern Milan functional urban area. Sci Total Environ 21:326-339

9. Huan H, Wang J, Teng Y (2012) Assessment and validation of groundwater vulnerability to nitrate based on a modified DRASTIC model: a case study in Jilin City of northeast China. Sci Total Environ 440:14-23

10. Shrestha S, Kafle R, Pandey VP (2017) Evaluation of index-overlay methods for groundwater vulnerability and risk assessment in Kathmandu Valley, Nepal. Sci Total Environ 575:779-790 
11. Dragon K (2006) Application of factor analysis to study contamination of a semi-confined aquifer (Wielkopolska Buried Valley aquifer, Poland). J Hydrol 331(1-2):272-279

12. El Alfy M (2013) Hydrochemical modeling and assessment of groundwater contamination in Northwest Sinai, Egypt. Water Environ Res 85(3):211-223

13. Kolsi SH, Bouri S, Hachicha W, Dhia HB (2013) Implementation and evaluation of multivariate analysis for groundwater hydrochemistry assessment in arid environments: a case study of Hajeb Elyoun-Jelma, Central Tunisia. Environ Earth Sci 70(5):2215-2224

14. Bradaï A, Douaoui A, Bettahar N, Yahiaoui I (2016) Improving the prediction accuracy of groundwater salinity mapping using indicator kriging method. J Irrig Drain Eng 142(7):04016023

15. Kitanidis P (1997) Introduction to geostatistics: application to hydrology. Cambridge University Press, Cambridge

16. Srivastava PK, Han D, Gupta M, Mukherjee S (2012) Integrated framework for monitoring groundwater pollution using a geographical information system and multivariate analysis. Hydrol Sci J 57(7):1453-1472

17. Panagopoulos GP, Angelopoulou D, Tzirtzilakis EE, Giannoulopoulos $P$ (2016) The contribution of cluster and discriminant analysis to the classification of complex aquifer systems. Environ Monit Assess 188(10):591

18. Adhikari K, Mal U (2019) Application of multivariate statistics in the analysis of groundwater geochemistry in and around the open cast coal mines of Barjora block, Bankura district, West Bengal, India. Environ Earth Sci 78(3):72

19. El Alfy M, Lashin A, Abdalla F, Al-Bassam A (2017) Assessing the hydrogeochemical processes affecting groundwater pollution in arid areas using an integration of geochemical equilibrium and multivariate statistical techniques. Environ Pollut 229:760-770

20. Baghapour MA, Talebbeydokhti N, Tabatabee H, Fadaei Nobandegani A (2014) Assessment of groundwater nitrate pollution and determination of groundwater protection zones using DRASTIC and composite DRASTIC (CD) models: the case of Shiraz unconfined aquifer. J Heal Sci Surveill Syst 2(2):54-65

21. Baghapour MA, Nobandegani AF, Talebbeydokhti N, Bagherzadeh S, Nadiri AA, Gharekhani M, Chitsazan N (2016) Optimization of DRASTIC method by artificial neural network, nitrate vulnerability index, and composite DRASTIC models to assess ground water vulnerability for unconfined aquifer of Shiraz Plain, Iran. J Environ Heal Sci Eng 14(1):13. https://doi.org/10.1186/ s40201-016-0254-y

22. Amiri $H$, Zare $M$, Widory $D$ (2015) Assessing sources of nitrate contamination in the Shiraz urban aquifer (Iran) using the $\delta^{15} \mathrm{~N}$ and $\delta^{18} \mathrm{O}$ dual-isotope approach. Isot Environ Health Stud 51(3):392-410

23. APHA (American Public Health Association) (2005) Standard method for examination of water and wastewater, $21 \mathrm{st}$ edn. APHA, AWWA, WPCF, Washington

24. ASTM D 512: 2012, Standard test methods for chloride ion in water

25. Sawyer CN, McCarty PL (1978) Chemistry of environmental engineering. Series in Water Resources and Environmental Engineering, 3rd edn. McGraw-Hill, New York

26. Kumar V, Sharma A, Chawla A, Bhardwaj R, Thukral AK (2016) Water quality assessment of river Beas, India, using multivariate and remote sensing techniques. Environ Monit Assess 188:137. https://doi.org/10.1007/s10661-016-5141-6

27. Kumar V, Sharma A, Minakshi Bhardwaj R, Thukral AK (2018) Temporal distribution, source apportionment, and pollution assessment of metals in the sediments of Beas river, India. Hum Ecol Risk Assess 24(8):2162-2181
28. Kumar V, Sharma A, Dhunna G, Chawla A, Bhardwaj R, Thukral AK (2017) A tabulated review on distribution of heavy metals in various plants. Environ Sci Poll Res 24(3):2210-2260

29. Kumar V, Sharma A, Bakshi P, Bhardwaj R, Thukral AK (2018) Multivariate analysis on the distribution of elements in plants. Acta Physiol Plant 40(11):187. https://doi.org/10.1007/s1173 8-018-2765-x

30. Kumar V, Sharma A, Bhardwaj R, Thukral AK (2019) Elemental composition of plants and multivariate analysis. Natl Acad Sci Lett 42(1):45-50

31. Kumar V, Sharma A, Kaur P, Sidhu GP, Bali AS, Bhardwaj R, Thukral AK, Cerda A (2019) Pollution assessment of heavy metals in soils of India and ecological risk assessment: a state-ofthe-art. Chemosphere 216:449-462. https://doi.org/10.1016/j. chemosphere.2018.10.066

32. Kumar V, Sharma A, Thukral AK, Bhardwaj R (2017) Water quality of River Beas, India. Curr Sci 112(6):1-20

33. Gvozdić V, Brana J, Malatesti N, Roland D (2012) Principal component analysis of surface water quality data of the River Drava in eastern Croatia (24 year survey). J Hydroinform 14(4):1051-1060

34. WHO (2011) WHO guidelines for drinking-water quality, 4th edn. World Health Organization, Washington, DC

35. Logeshkumaran A, Magesh NS, Godson PS, Chandrasekar N (2015) Hydro-geochemistry and application of water quality index (WQI) for groundwater quality assessment, Anna Nagar, part of Chennai City, Tamil Nadu, India. Appl Water Sci 5(4):335-343

36. Nagarajan R, Rajmohan N, Mahendran U, Senthamilkumar $S$ (2010) Evaluation of groundwater quality and its suitability for drinking and agricultural use in Thanjavur city, Tamil Nadu, India. Environ Monit Assess 171(1-4):289-308

37. Todd DK, Mays LW (2005) Ground-water hydrology. Wiley, New York

38. Beaver MB, Beaver JR, Mendenhall W (2012) Introduction to Probability and Statistics. Cengage Learning, New Delhi

39. Rezaei A, Hassani H (2017) Hydrogeochemistry study and groundwater quality assessment in the north of Isfahan, Iran. Environ Geochem Heal 40(2):583-608

40. Rao NS (2002) Geochemistry of groundwater in parts of Guntur district, Andhra Pradesh, India. Environ Geol 41:552-562

41. Rao SVL (2003) Cluster analysis of groundwater quality data of VenkatagiriTaluq, Nellore district, Andhra Pradesh. J Geol Soc India 62:447-454

42. Ganyaglo SY, Banoeng-Yakubo B, Osae S, Dampare SB, Fianko JR (2011) Water quality assessment of groundwater in some rock types in parts of the eastern region of Ghana. Environ Earth Sci 62(5):1055-1069

43. Wilcox LV (1955) Classification and use of irrigation water. USDA circular 969. US Department of Agriculture, Washington, DC, $p$ 19

44. Hem JD (1991) Study and interpretation of the chemical characteristics of natural water. Book 2254, 3rd edn. Scientific Publishers, Jodhpur

45. Richards LA (1954) Diagnosis and improvement of saline alkali soils: agriculture, Handbook 60, vol 160. US Department of Agriculture, Washington, DC

46. Matthess G (1982) The properties of groundwater. Wiley, New York

47. Soltan ME (1998) Characterization, classification, and evaluation of some groundwater samples in upper Egypt. Chemosphere 37:735-745

48. Soltan ME (1999) Evaluation of groundwater quality in Dakhla Oasis (Egyptian Western Desert). Environ Monit Assess 57:157-168 
49. Kaiser HF (1958) The varimax criterion for analytic rotation in factor analysis. Psychometrika 23(3):187-200

50. Jiang $Y$, Wu Y, Groves $C$, Yuan D, Kambesis P (2009) Natural and anthropogenic factors affecting the groundwater quality in the Nandong karst underground river system in Yunan, China. J Cont Hydrol 109(1-4):49-61

51. Liu CQ, Lang YC, Satake H, Wu J, Li SL (2008) Identification of anthropogenic and natural inputs of sulfate and chloride into the karstic ground water of Guiyang, SW China: combined $\delta^{37} \mathrm{Cl}$ and $\delta^{34} S$ approach. Environ Sci Technol 42(15):5421-5427

52. Selvakumar S, Ramkumar K, Chandrasekar N, Magesh NS, Kaliraj $S$ (2017) Groundwater quality and its suitability for drinking and irrigational use in the Southern Tiruchirappalli district, Tamil Nadu, India. Appl Water Sci 7(1):411-420

53. Ravikumar P, Somashekar RK (2017) Principal component analysis and hydrochemical facies characterization to evaluate groundwater quality in Varahi river basin, Karnataka state, India. Appl Water Sci 7(2):745-755

Publisher's Note Springer Nature remains neutral with regard to jurisdictional claims in published maps and institutional affiliations. 